\title{
Morphological and functional characterization of large antral follicles in three breeds of sheep with different ovulation rates
}

\author{
R. Webb, I. K. Gauld and M. A. Driancourt*
}

AFRC, Institute of Animal Physiology and Genetics Research, Edinburgh Research Station, Roslin, Midlothian EH25 9PS, UK; and *INRA, Reproductive Physiology, 37380 Nouzilly, France

\begin{abstract}
Summary. Morphological and functional features of large ovarian follicles from three breeds of sheep, with different ovulation rates (Finnish Landrace $\mathrm{N}=12$, Finnish Landrace $\times$ Scottish Blackface $N=16$, Merino $\times$ Scottish Blackface $N=16$ ) were compared by integrating three techniques; ink labelling, in-vitro oestradiol production and morphological classification. The follicles were removed at two stages of the follicular phase, $1(\mathrm{PG}+1)$ or $2(\mathrm{PG}+2)$ days after PGF- $2 \alpha$ treatment and compared after monitoring their rates of growth with the use of ink labelling. After ovariectomy all follicles $\geqslant 1 \mathrm{~mm}$ in diameter were dissected, and the 8 largest were incubated individually for $2 \mathrm{~h}$ to assess their ability to secrete oestradiol and testosterone. After incubation the follicles were processed for histological examination and checked for atresia. An analysis of the follicle population was based on in-vitro oestradiol secretion rates in all three breeds; an oestrogen-active population producing 500-8100 pg oestra$\mathrm{diol} / \mathrm{ml} / \mathrm{h}$ and an oestrogen-inactive population producing $0-499 \mathrm{pg}$ oestradiol $/ \mathrm{ml} / \mathrm{h}$. A comparison of the 3 approaches demonstrated agreement on $94.3 \pm 1.2 \%$ of occasions. Ink-labelling demonstrated that all follicles identified as oestrogen-active were increasing in size. Within oestrogen-active follicles significant correlations were detected between oestradiol production and testosterone production $(r=0.42)$, oestradiol production and granulosa cell number $(r=0.45)$ and between oestradiol production and mitotic index $(r=-0 \cdot 38)$. A regression model fitting breed, stage of atresia, granulosa cell number, in-vitro testosterone production and mitotic index demonstrated that granulosa cell number is a characteristic which contributes significantly to the variation of invitro oestradiol production in oestrogen-active and oestrogen-inactive follicles. There was no significant difference between breeds in the mean number of ink-labelled follicles growing from Day $P G-1$ to Day $P G+1$. There was a significant difference between the breeds in the number of ink-labelled follicles growing between Days $\mathrm{PG}+1$ and $\mathrm{PG}+2$ (Days 1 and 2 of the follicular phase), the number being similar to the ovulation rate for the breed. The majority of the oestrogen-active follicles had been recruited by Day PG -1 , although in the Finnish Landrace genotypes more than $30 \%$ were recruited on or after Day PG +1 compared to less than $10 \%$ in Merino $\times$ Scottish Blackface ewes. Although mean oestradiol production by oestrogen-active follicles was similar in all three breeds, oestrogen-active follicles in Finnish Landrace ewes had significantly reduced granulosa cell number and mitotic index compared to the other breeds.
\end{abstract}

These results demonstrate: (1) a good agreement between the three criteria used to characterize follicles, (2) that the mechanisms controlling follicular recruitment into the population of gonadotrophin-dependent follicles are different from the mechanisms controlling the selection of the follicles destined to ovulate and (3) that despite no 
between-breed differences for in-vitro oestradiol production by oestrogen-active follicles, the follicles of Finnish Landrace ewes had significantly lower numbers of granulosa cells and mitotic index, indicating alterations in morphological and functional differentiation associated with prolificacy.

Keywords: sheep; prolificacy; steroidogenesis; follicular growth

\section{Introduction}

Much of the information on ovarian follicular differentiation in breeds of sheep with different prolificacy has been obtained using classical histological techniques (Turnbull et al., 1977; Cahill \& Mauléon, 1980). The major limitation of this approach is that each specimen represents only a single time point, whereas the growth and differentiation of follicles is a dynamic process, and so differences between ewes may obscure the physiological processes (Driancourt \& Cahill, 1984). Ink labelling at successive laparotomies has been used to monitor the growth and regression of individual follicles in sheep (Driancourt \& Cahill, 1984). The application of this approach has suggested that higher ovulation rate $(\geqslant 3)$ can be achieved by different patterns of follicular recruitment and atresia (Driancourt et al., 1986). However, the limitation of this approach is that no information on the stage of differentiation of follicles is obtained. Using biochemical techniques it has been demonstrated that as sheep follicles grow and mature they acquire a number of characteristics, including significant numbers of LH receptors in the granulosa cell layer and an ability to produce large quantities of oestradiol (Carson et al., 1979; England et al., 1981b; Webb \& England, 1982a). Because there is a significant correlation between in-vitro oestradiol production and both ovarian vein and follicular fluid oestradiol concentrations (Webb \& Gauld, 1985a, 1987), oestradiol production can be measured by incubating follicles in vitro (Webb \& England, 1982b). This measure can therefore be used to assess the stage of follicular differentiation, although as with the histological studies information at only a single time point is obtained.

The aims of this study were firstly, to compare these three methods, namely ink labelling, morphological classification and in-vitro oestradiol production, to study the dynamics of follicular growth. Secondly, to use all 3 methods, in 3 breeds of sheep with different ovulation rates, to compare in vivo the pattern of follicular recruitment into the population of gonadotrophindependent follicles, and to investigate whether there are differences between the three breeds in the selection of these follicles into the preovulatory follicle pool. Thirdly, to use in-vitro techniques to assess whether differences in morphological and functional characteristics can be associated with increasing prolificacy.

\section{Materials and Methods}

\section{Animals}

The experiment was carried out during the breeding season (November and December) in three breeds of sheep; Finnish Landrace $(\mathrm{N}=12)$, Finnish Landrace $\times$ Scottish Blackface $(\mathrm{N}=16)$ and Merino $\times$ Scottish Blackface $(\mathrm{N}=16)$. The ewes were housed indoors at the Large Animal Unit, Dryden, Midlothian, and fed on hay and concentrates as dictated by normal husbandry practice.

\section{Experimental design}

The oestrous cycles of all ewes were synchronized with a 12-day intravaginal treatment with progestagenimpregnated sponges (MAP, Veramix: Upjohn Ltd, Crawley, Sussex, UK); oestrus being taken as Day 0 of the treatment cycle. All ewes were injected with PGF-2 $\alpha$ (125 $\mu \mathrm{g}$ Estrumate; ICI, Macclesfield, Cheshire, UK) at 2I:00 h on Day 10 (Day PG + 0; see Fig. 1). Blood samples were collected daily from Day 1 to Day 12 to confirm that luteolysis had occurred and to delineate the exact stage of the oestrous cycle when the ovaries were removed. Serum was stored at $-20^{\circ} \mathrm{C}$ until assayed for progesterone. 


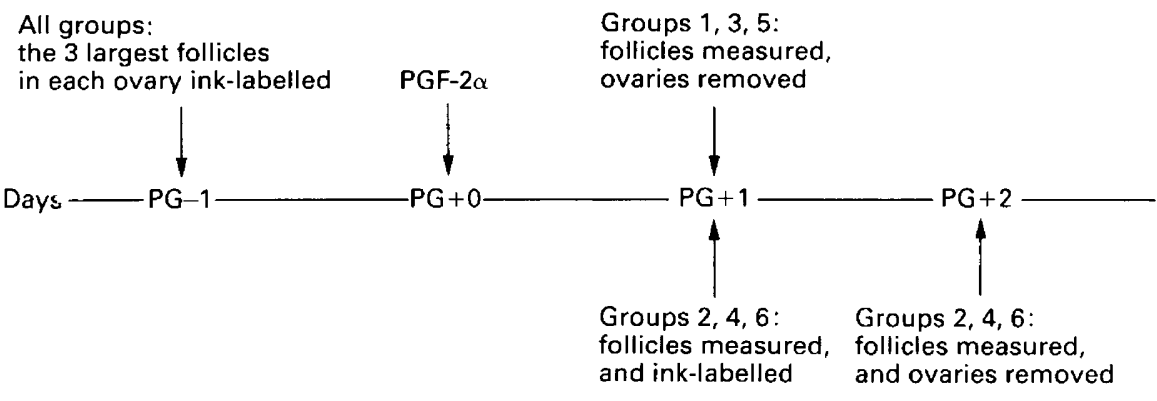

Fig. 1. The experimental design. Groups 1 and 2 are Finnish Landrace $(\mathrm{N}=6 /$ group $)$; Groups 3 and 4 are Finnish Landrace $\times$ Scottish Blackface $(N=8 /$ group); Groups 5 and 6 are Merino $\times$ Scottish Blackface ( $\mathrm{N}=8$ /group). PGF- $2 \alpha$ injection on Day $\mathrm{PG}+0$ was equivalent to Day 10 of the treatment oestrous cycle.

The ewes were divided into 6 experimental groups ( 2 groups per breed) as shown in Fig. 1. Ewes in Group 1 (Finnish Landrace, $N=6$ ), Group 3 (Finnish Landrace $\times$ Scottish Blackface, $N=8$ ) and Group 5(Merino $\times$ Scottish Blackface, $N=8$ ) were ovariectomized on Day PG +1 (i.e. the day after PGF- $2 \alpha$ injection and equivalent to the first day of the follicular phase). Ewes in Group 2 (Finnish Landrace, $N=6$ ), Group 4 (Finnish Landrace $\times$ Scottish Blackface, $\mathrm{N}=8$ ) and Group 6 (Merino $\times$ Scottish Blackface, $\mathrm{N}=8$ ) were ovariectomized on Day PG +2 (i.e. 2 days after PGF-2 $\alpha$ injection and equivalent to the 2 nd day of the follicular phase). All ewes were checked for oestrus immediately before ovariectomy. On Day PG -1 all ewes underwent a first laparotomy, during which the 3 largest follicles on the surface of each ovary were measured and ink-labelled (Driancourt \& Cahill, 1984). A map of each ovary was drawn to help distinguish between follicles at successive laparotomies. On Day PG +1 (at least $12 \mathrm{~h}$ after PGF-2 $\alpha$ injection) ewes in all groups underwent a second laparotomy at which the 3 largest follicles on each ovary, plus any follicles previously ink-labelled, were measured. On Day PG +1 the ovaries of ewes in Groups 1,3 and 5 were also removed. Ewes in Groups 2, 4 and 6 then underwent a third laparotomy on Day PG +2 (at least $36 \mathrm{~h}$ after PGF- $2 \alpha$ injection) at which the 3 largest follicles on each ovary, plus all follicles previously ink-labelled, were measured; the ovaries were then removed. All ewes were anaesthetized initially with a single intravenous injection of $20 \mathrm{ml}$ Saffan $(12 \mathrm{mg} / \mathrm{ml}$ of alphaxalone $(0.9 \%)$ and alphadolone $(0.3 \%)(\mathrm{w} / \mathrm{v})$ : Glaxo, Greenford, Middlesex, UK) as Saffan has been shown not to have an effect on the pulsatile release of LH (Clarke \& Doughton, 1983). The ewes were then maintained under deep surgical anaesthesia by infusing Saffan as necessary, usually $10-15 \mathrm{ml}$ (in $2-5 \mathrm{ml}$ amounts) over a $30-45$-min period.

After ovariectomy all follicles $\geqslant 1 \mathrm{~mm}$ in diameter were carefully dissected to assess the large antral follicle population. Up to 8 of the largest follicles per ovary, including the ink-labelled follicles, were incubated individually for $2 \mathrm{~h}$ (two 1 -h incubations) in $1 \mathrm{ml} \mathrm{M} 199$ plus $20 \mathrm{~mm}$-Hepes at $37^{\circ} \mathrm{C}$ in $95 \%$ air and $5 \% \mathrm{CO}_{2}$ (Webb \& England, $1982 \mathrm{~b}$ ). The incubation medium was stored at $-20^{\circ} \mathrm{C}$ to await assay for oestradiol and testosterone.

\section{Histological techniques and follicle classification}

The incubated follicles were fixed in Bouin-Hollande's solution and then sectioned at a thickness of $10 \mu \mathrm{m}$. One section out of 6 was mounted and stained with haematoxylin. Measurements of follicle size and granulosa cell number were made in the histological section with the largest diameter and the results calculated according to Pedersen (1970) and Gougeon (1981). All follicles were assessed as normal or atretic using the following classification.

Class 1 -normal; fewer than 5 pycnotic bodies in the granulosa layer of the section studied.

Class 2 - early atresia I; 5-100 pycnotic bodies.

Class 3 - early atresia II; 100-200 pycnotic bodies.

Class 4-advanced atresia I; numerous pycnotic bodies, but still a distinct granulosa cell layer.

Class 5-advanced atresia II; numerous pycnotic bodies, but no distinct granulosa cell layer.

Class 6-late atresia; no granulosa cells present except around the oocyte.

Follicles in very late atresia, in which no oocyte could be found, were not considered in this study. The mitotic index was calculated as the ratio between the number of cells undergoing cell division and the number of granulosa cells in the section studied. Likewise, the pycnotic index was the ratio between the number of pycnotic nuclei and the number of granulosa cells in the section studied.

\section{Hormone assays}

Oestradiol and testosterone. Concentrations of oestradiol and testosterone in the culture media were determined in duplicate using assays previously described (Webb et al., 1985). It was found that both oestradiol and testosterone 
could be analysed in the media without prior extraction (Webb \& England, 1982b). All samples were measured in single assays. The intra-assay coefficient of variation for oestradiol was $8.7 \%$ and that for testosterone was $14.6 \%$. The minimum detectable values were $6.3 \mathrm{pg}$ oestradiol $/ \mathrm{ml}$ and $25.5 \mathrm{pg}$ testosterone $/ \mathrm{ml}$.

Progesterone. Concentration of progesterone in peripheral serum was determined using a radioimmunoassay described previously (Corrie et al., 1981; Webb, 1987). The minimum detectable value was $0.23 \mathrm{ng} / \mathrm{ml}$. The inter-assay and intra-assay coefficients of variation were $4.0 \%$ and $7.5 \%$ respectively.

\section{Statistical analyses}

Unless otherwise indicated, significant differences between groups were calculated using analysis of variance and incorporating Scheffe's multiple comparison test (Scheffe, 1959). The variables used in this analysis were sheep, breed, group, follicle diameter, granulosa cell number, in-vitro oestradiol and testosterone production, stage of atresia and mitotic and pycnotic indices. Unless indicated, all data were transformed to natural logarithms before analysis to normalize the distributions. Separate least-squares regression models were used to explain the variation in oestradiol production within the oestrogen-active and oestrogen-inactive follicle populations. Correlations were also calculated for the variables within these two populations.

\section{Results}

\section{Oestrous behaviour and peripheral progesterone concentration}

None of the ewes ovariectomized on Day PG +1 (Groups 1, 3 and 5) showed oestrous behaviour. However, in Groups 2, 4 and 6, ovariectomized on Day PG +2 (at least $36 \mathrm{~h}$ after PGF-2 $\alpha$ ), $5 / 6$ Finnish Landrace, 5/8 Finnish Landrace $\times$ Scottish Blackface and 5/8 Merino $\times$ Scottish Blackface were in oestrus.

All ewes had a luteal-phase concentration of progesterone $(>0.5 \mathrm{ng} / \mathrm{ml})$ on the day of PGF $-2 \alpha$ treatment (Day PG +0 ), except for 1 of the Finnish Landrace $\times$ Scottish Blackface ewes (Group 3 ); results from this animal were therefore omitted from the calculations. There was no significant difference between the groups in the peak luteal-phase concentrations ( \pm s.e.m.) of progesterone, the mean peak concentrations for each breed being $2.4 \pm 0.4,2.6 \pm 0.2$ and $2.6 \pm 0.3 \mathrm{ng} / \mathrm{ml}$ for Finnish Landrace, Finnish Landrace $\times$ Scottish Blackface and Merino $\times$ Scottish Blackface respectively.

\section{Definition of follicle populations using in-vitro oestradiol production}

A frequency distribution of the follicle population in the three breeds, based on the in-vitro oestradiol secretion rates, demonstrated a bimodal distribution in all three breeds. There was no effect of time of ovariectomy on this distribution, and so all the data have been pooled as shown in Fig. 2. Based on this bimodal pattern, follicles secreting $\geqslant 500 \mathrm{pg} / \mathrm{ml} / \mathrm{h}$ have been designated oestrogen-active and the remaining follicles designated oestrogen-inactive.

From all the breeds a total of 112 oestrogen-active follicles were identified; of these 12 were either ruptured during dissection or damaged during histological processing. The remaining 269 incubated follicles were oestrogen-inactive. The morphology data demonstrated that 94 of the remaining 100 oestrogen-active follicles were normal (Class 1). Of the 6 follicles which were not classified as normal, 3 were in Class 2, 2 in Class 4 and one in Class 6 of atresia. The ink-labelling results indicated that all follicles identified as oestrogen-active were growing. A comparison of all 3 approaches, namely in-vitro oestradiol production (producing $\geqslant 500 \mathrm{pg} / \mathrm{ml} / \mathrm{h}$ ), ink labelling (increase in size) and morphology (healthy), demonstrated agreement on $94 \cdot 3 \pm 1 \cdot 2 \%$ of occasions.

There was a significant breed difference $(P<0.05)$ in the mean number of corpora lutea and oestrogen-active follicles (Table 1), although within a breed there was no significant difference between Days PG +1 and PG +2 for any of the three characteristics. Finnish Landrace ewes had significantly more preovulatory follicles (a preovulatory follicle being defined as a Class 1 oestrogenactive follicle) than did the other two breeds, although there was no significant difference between the Finnish Landrace $\times$ Scottish Blackface and Merino $\times$ Scottish Blackface ewes. 


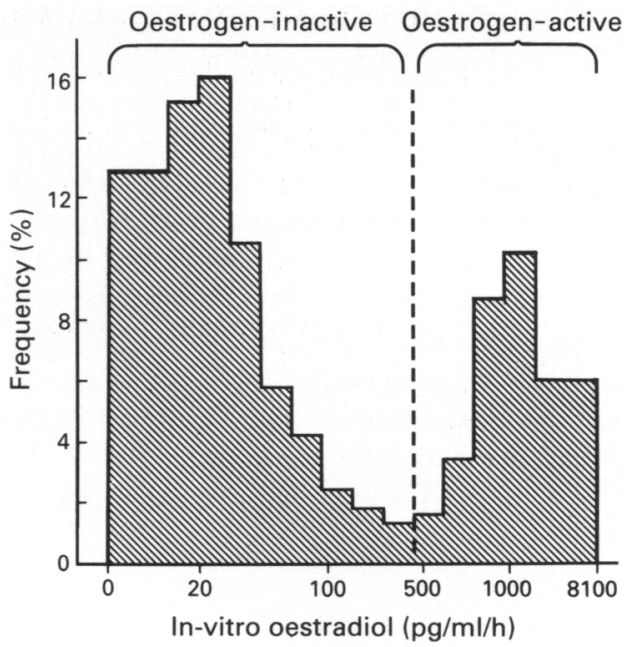

Fig. 2. The percentage distribution of the total follicle population $(100 \%)$ based on in-vitro oestradiol production $(\mathrm{pg} / \mathrm{ml} / \mathrm{h})$. As sheep in all the 3 breeds, on both days of ovariectomy $(P G+1$ and $P G+2)$, had the same distribution pattern, the results have been pooled giving a total population of 381 follicles from 48 ewes. Note that the in-vitro oestradiol secretion rates are plotted on a natural logarithm scale because the overall population was not normally distributed. The results demonstrate a bimodal distribution with two populations designated as oestrogen-inactive or oestrogen-active.

Table 1. Ovulation rate*, number of antral follicles ( $\geqslant 1.0 \mathrm{~mm}$ in diameter), oestrogen-active follicles $\dagger$ and preovulatory follicles $\ddagger$ during the follicular phase of the oestrous cycle $\$$

\begin{tabular}{|c|c|c|c|}
\hline & $\begin{array}{l}\text { Finnish } \\
\text { Landrace }\end{array}$ & $\begin{array}{c}\text { Finnish Landrace } \times \\
\text { Scottish Blackface }\end{array}$ & $\begin{array}{c}\text { Merino } \times \\
\text { Scottish Blackface }\end{array}$ \\
\hline No. of corpora lutea & $\begin{array}{l}3 \cdot 3 \pm 0 \cdot 3^{a} \\
\quad(12)\end{array}$ & $\begin{array}{l}2 \cdot 4 \pm 0 \cdot 2^{b} \\
(16)\end{array}$ & $\begin{array}{c}1 \cdot 4 \pm 0 \cdot 1^{\mathrm{c}} \\
(16)\end{array}$ \\
\hline $\begin{array}{l}\text { Total no. of antral } \\
\text { follicles per breed }\end{array}$ & 207 & 347 & 358 \\
\hline $\begin{array}{l}\text { No. of antral follicles } \\
\text { per ewe }\end{array}$ & $\begin{array}{c}17 \cdot 3 \pm 1 \cdot 6^{\mathrm{a}} \\
(12)\end{array}$ & ${ }_{(15)}^{21 \cdot 4 \pm 1 \cdot 4^{b}}$ & $\frac{22 \cdot 9 \pm 1 \cdot 6^{b}}{(16)}$ \\
\hline $\begin{array}{l}\text { No. of oestrogen-active } \\
\text { follicles }\end{array}$ & $\begin{array}{l}3 \cdot 6 \pm 0 \cdot 3^{a} \\
\quad(12)\end{array}$ & $\begin{array}{l}2 \cdot 7 \pm 0 \cdot 2^{b} \\
(15)\end{array}$ & $\begin{array}{l}1 \cdot 8 \pm 0 \cdot 1^{\mathrm{c}} \\
\quad(16)\end{array}$ \\
\hline $\begin{array}{l}\text { No. of preovulatory } \\
\text { follicles }\end{array}$ & $\begin{array}{l}3 \cdot 5 \pm 0 \cdot 3^{a} \\
(10)\end{array}$ & $2 \cdot 4 \pm \frac{0 \cdot 4^{b}}{(9)}$ & $\begin{array}{l}1 \cdot 7 \pm 0 \cdot 3^{b} \\
(10)\end{array}$ \\
\hline
\end{tabular}

Values are mean \pm s.e.m. for the no. of ewes indicated in parentheses.

*Number of corpora lutea counted on Day PG -1 .

$\dagger$ An oestrogen-active follicle produces $\geqslant 500 \mathrm{pg}$ oestradiol $/ \mathrm{ml} / \mathrm{h}$ in vitro.

$\ddagger$ A preovulatory follicle is a normal (Class 1 ) oestrogen-active follicle.

$\S$ Results from Days PG +1 and $P G+2$ have been pooled.

Values with different superscripts across each row of overall means are significantly different $(P<0.05)$.

\section{Antrum follicle population and dynamics of follicular growth}

Based on diameter, measured at the time of dissection, the Finnish Landrace ewes had significantly fewer antral follicles $\geqslant 1.0 \mathrm{~mm}$ diameter, despite having a significantly higher ovulation rate, 
compared with the other two breeds (Table 1). The overall percentage distribution of all follicles for each breed is shown in Fig. 3. The pattern of distribution indicated that the Finnish Landrace ewes had a higher proportion of follicles in the $4 \cdot 1-6.0 \mathrm{~mm}$ diameter range $(19 \%)$, followed by Finnish Landrace $\times$ Scottish Blackface $(11 \%)$ and then the Merino $\times$ Scottish Blackface $(7 \%)$ ewes. A log linear model with Poisson errors was fitted to the data, but even after incorporating breed and follicle size, the model did not explain a significant proportion of the variation. However, a significant proportion of the variation $(P<0.01)$ was explained by adding an effect $(1$ d.f.) for the difference between the Finnish Landrace ewes and the other two breeds for the follicles $>6.0 \mathrm{~mm}$ in diameter. Thus Finnish Landrace ewes have significantly fewer follicles $>6.0 \mathrm{~mm}$ in diameter than would be expected if they exhibited the same pattern of follicular growth as do the other two groups (Scottish Blackface crosses). The median size range for oestrogen-active follicles was $4-5 \mathrm{~mm}$, accounting for $52 \%$ of the oestrogen-active follicle population. Of the follicles incubated, $93 \%$ of the oestrogen-active follicles were in the 3-6 mm diameter range and $82 \%$ of the oestrogen-inactive follicle population were in the $1-3 \mathrm{~mm}$ range.

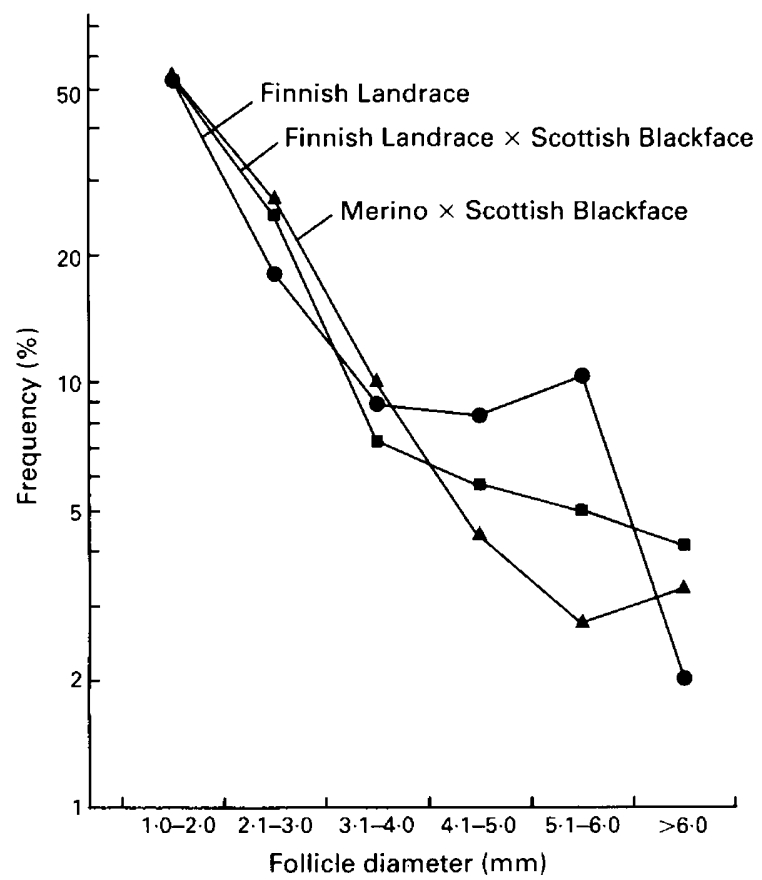

Fig. 3. The percentage distribution of the total follicle population from ewes of the three breeds of sheep based on diameter (mm). There were 202 follicles in the Finnish Landrace (12 ewes), 342 follicles in the Finnish Landrace $\times$ Scottish Blackface (16 ewes) and 367 follicles in the Finnish Landrace $\times$ Merino ewes (16 ewes). The total number of follicles $\geqslant 1.0 \mathrm{~mm}$ in diameter for each breed is equal to $100 \%$.

There was no significant difference between breeds in the mean number of ink-labelled follicles growing between Days PG -1 to PG +1 (Finnish Landrace: $4 \cdot 4 \pm 0 \cdot 3$; Finnish Landrace $x$ Scottish Blackface: $4 \cdot 6 \pm 0 \cdot 5$; Merino $\times$ Scottish Blackface: $4 \cdot 4 \pm 0 \cdot 5)$. However, there was a significant difference $(P<0.05)$ between the breeds in the number of ink-labelled follicles growing between Days PG +1 and PG +2 (Finnish Landrace: $3 \cdot 1 \pm 0 \cdot 4$; Finnish Landrace $\times$ Scottish Blackface: $2 \cdot 0 \pm 0 \cdot 4$; Merino $\times$ Scottish Blackface: $1 \cdot 6 \pm 0 \cdot 6$ ); these values were similar to the ovulation rate (Table 1 ). 
The percentage of oestrogen-active follicles that had been either ink-labelled on Day PG -1 or Day $P G+1$ and were still present on Day PG +1 or Day PG +2 are shown in Table 2. Although the majority of the oestrogen-active follicles present on Day PG +2 had been ink-labelled on Day PG -1 , approximately $30 \%$ of the oestrogen-active follicles in the Finnish Landrace group were not labelled until Day PG +1 compared with only $6 \%$ in the Merino $\times$ Scottish Blackface ewes. Similar conclusions were also reached when the result were expressed as a proportion of the total follicles/breed/day $(P<0.05$; contingency tables and $t$ test $)$ rather than the proportion of follicles/ ewe for each breed. Fitting log linear models, with binomial errors, demonstrated that significantly fewer $(P<0.05)$ oestrogen-active follicles present on Day PG +2 in the Finnish Landrace genotypes had been labelled on Day PG -1 compared to the Merino $\times$ Scottish Blackface groups. In 6/6 Finnish Landrace, 7/8 Finnish Landrace $\times$ Scottish Blackface and 8/8 Merino $\times$ Scottish Blackface ewes the largest oestrogen-active follicle present on Day PG +2 had been previously labelled on Day PG - 1 .

Table 2. Between-breed comparisons of the proportion (percentage mean \pm s.e.m.) of oestrogen-active follicles per ewe (no. in parentheses) present on Days $\mathrm{PG}+1$ or $\mathrm{PG}+2^{*}$ that had previously been ink-labelled on Days $\mathrm{PG}-1$ or $\mathrm{PG}+1$

\begin{tabular}{|c|c|c|c|}
\hline $\begin{array}{l}\text { Stage of the } \\
\text { oestrous cycle }\end{array}$ & $\begin{array}{l}\text { Finnish } \\
\text { Landrace }\end{array}$ & $\begin{array}{l}\text { Finnish Landrace } \times \\
\text { Scottish Blackface }\end{array}$ & $\begin{array}{c}\text { Merino } x \\
\text { Scottish Blackface }\end{array}$ \\
\hline$P G-1$ to $P G+1$ & $67 \cdot 9 \pm \frac{ \pm}{(12)} 7 \cdot 2$ & $\underset{(15)}{79 \cdot 8 \pm}$ & $\begin{array}{c}82 \cdot 3 \pm 6 \cdot 0 \\
(16)\end{array}$ \\
\hline$P G-1$ to $P G+2$ & $58 \cdot 2 \pm \frac{11 \cdot 4^{\mathrm{a}}}{(6)}$ & $\frac{68 \cdot 5 \pm 10 \cdot 2^{b}}{(8)}$ & $93 \cdot 8 \underset{(8)}{ \pm} 6 \cdot 3^{c}$ \\
\hline$P G+1$ to $P G+2$ & $88 \cdot 6 \pm \frac{(6)}{5 \cdot 1}$ & $92 \cdot 0 \pm \frac{(8)}{5 \cdot 3}$ & $100 \cdot 0 \pm 0.0$ \\
\hline
\end{tabular}

There was no significant difference in the growth rates $(\mathrm{mm} /$ day) of oestrogen-active follicles when comparing between breeds on the same day of measurement (Table 3). However, comparisons between days ( $P G+1$ versus $P G+2$ ), within breed, showed that for the Merino $\times$ Scottish Blackface ewes there was a significantly slower growth rate $(P<0.05)$ during the late follicular phase (Days $P G+1$ to $P G+2$ ) compared with the late luteal phase to early follicular phase (Days $P G-1$ to Day $P G+1)$.

Table 3. Mean ( \pm s.e.m) follicular growth rates of oestrogen-active follicles (mm/day)

\begin{tabular}{|c|c|c|c|c|c|c|}
\hline \multirow[b]{2}{*}{$\begin{array}{l}\text { Days of } \\
\text { measurement }\end{array}$} & \multicolumn{2}{|c|}{ Finnish Landrace } & \multicolumn{2}{|c|}{$\begin{array}{c}\text { Finnish Landrace } \times \\
\text { Scottish Blackface }\end{array}$} & \multicolumn{2}{|c|}{$\begin{array}{c}\text { Merino } x \\
\text { Scottish Blackface }\end{array}$} \\
\hline & $\begin{array}{c}\text { Day } \\
\text { PG }+1^{*}\end{array}$ & $\begin{array}{c}\text { Day } \\
\text { PG }+2^{*}\end{array}$ & $\begin{array}{l}\text { Day } \\
\text { PG +1 }\end{array}$ & $\begin{array}{c}\text { Day } \\
\text { PG }+2\end{array}$ & $\begin{array}{c}\text { Day } \\
\text { PG }+1\end{array}$ & $\begin{array}{c}\text { Day } \\
\mathbf{P G}+2\end{array}$ \\
\hline$P G-1$ to $P G+1$ & $0.7 \pm 0.1$ & $0 \cdot 7 \pm 0 \cdot 1$ & $0.8 \pm 0.2$ & $0.8 \pm 0.1$ & $0.8 \pm 0.1$ & $1 \cdot 0^{\mathrm{a}} \pm 0 \cdot 1$ \\
\hline$P G+1$ to $P G+2$ & - & $0.8 \pm 0.2$ & - & $0.5 \pm 0.2$ & - & $0 \cdot 6^{\mathrm{b}} \pm 0 \cdot 1$ \\
\hline
\end{tabular}

*Day of ovariectomy.

The number of follicles per group ranged from 13 to 26 .

Values with different superscripts are significantly different $(P<0.05)$. 


\section{Morphological and functional characteristics}

Oestrogen-active follicles. There was no difference between breeds and no effect of the day of ovariectomy on follicular diameter (Table 4). Despite no significant differences in follicular diameter, the Finnish Landrace ewes had significantly $(P<0.01)$ fewer granulosa cells for follicles of a given size than did ewes of the other two breeds (Table 4). However, the mean total number of granulosa cells in oestrogen-active follicles, expressed on a per ewe basis, indicated no significant differences between the Finnish Landrace $\left(4.66 \pm 0.41 \times 10^{6} ; \mathrm{N}=9\right)$ and the Finnish Landrace $\times$ Scottish Blackface $\left(5.08 \pm 0.37 \times 10^{6} ; \mathrm{N}=14\right)$ ewes, but the Merino $\times$ Scottish Blackface ewes $\left(3.33 \pm 0.22 \times 10^{6} ; \mathrm{N}=14\right)$ had a significantly lower $(P<0.05)$ total number of granulosa cells per ewe. The Finnish Landrace ewes also had a significantly lower mitotic index than the Merino $\times$ Scottish Blackface animals, with the Finnish Landrace $\times$ Scottish Blackface ewes intermediate (Table 4).

Table 4. Geometric mean ( \pm s.e.m.) follicular characteristics of oestrogen-active follicles

\begin{tabular}{|c|c|c|c|c|}
\hline & $\begin{array}{l}\text { Finnish } \\
\text { Landrace }\end{array}$ & $\begin{array}{l}\text { Finnish Landrace } \times \\
\text { Scottish Blackface }\end{array}$ & \multicolumn{2}{|c|}{$\begin{array}{c}\text { Merino } x \\
\text { Scottish Blackface }\end{array}$} \\
\hline No. of follicles* & 39 & 28 & & 27 \\
\hline $\begin{array}{l}\text { In-vitro oestradiol production } \\
(\mathrm{ng} / \mathrm{ml} / \mathrm{h})\end{array}$ & \pm 0.2 & \pm 0.2 & $2 \cdot 2$ & \pm 0.2 \\
\hline Follicle diam. $\dagger(\mathrm{mm})$ & $\pm 0 \cdot 1$ & \pm 0.2 & $5 \cdot 8$ & $\pm 0 \cdot 2$ \\
\hline Granulosa cell no. $\left(\times 10^{-6}\right)$ & $1 \cdot 30 \pm 0 \cdot 08^{\mathrm{a}}$ & $1 \cdot 7 \mathrm{I} \pm 0 \cdot 12^{b}$ & $1 \cdot 79$ & $\pm 0 \cdot 14^{b}$ \\
\hline Mitotic Index (\%) & $0.089 \pm 0.017^{\mathrm{a}}$ & $0.125 \pm 0.029^{\mathrm{ab}}$ & $0 \cdot 207$ & $\pm 0.041^{b}$ \\
\hline Pycnotic Index $(\%)$ & $0.07 \pm 0.02$ & $0.10 \pm 0.02$ & 0.08 & \pm 0.02 \\
\hline
\end{tabular}

*Follicles obtained on Day PG +1 and Day PG +2 have been pooled because there was no effect of day of ovariectomy for in-vitro oestradiol production.

†The follicular diameter results were not transformed before analysis and are presented as arithmetic means.

For each of the follicle characteristics means with different superscripts are significantly different $(P<0.05)$.

There was no effect of day of ovariectomy within breeds and no significant difference between breeds for in-vitro oestradiol production. A regression model and fitting breed, atresia, granulosa cell number and in-vitro testosterone production showed that the number of granulosa cells $(P<0.05)$ and the mitotic index $(P<0.001)$ are characteristics which contribute significantly to the variation of in-vitro oestradiol production. There were also significant positive correlations between in-vitro oestradiol production and both in-vitro testosterone production $(n=93$; $r=0.42 ; P<0.001)$, follicular diameter $(n=93 ; r=0.51, P<0.001)$ and granulosa cell number $(n=93 ; r=0.45, P<0.001)$, but a significantly negative correlation with mitotic index $(n=93$; $r=-0.38, P<0.001)$. Granulosa cell number was also significantly correlated with follicular diameter $(n=93 ; r=0.80, P<0.001)$. There was a significant difference between breeds for invitro testosterone production (Finnish Landrace: $1.8 \pm 0.2 \mathrm{ng} / \mathrm{ml} / \mathrm{h}$; Finnish Landrace $\times$ Scottish Blackface: $2.5 \pm 0.4 \mathrm{ng} / \mathrm{ml} / \mathrm{h}$ and Merino $\times$ Scottish Blackface: $3.5 \pm 0.5 \mathrm{ng} / \mathrm{ml} / \mathrm{h} ; P<0.01)$. There was also a significant effect of day of ovariectomy, with each breed having a significantly higher concentration of in-vitro testosterone production on Day $\mathrm{PG}+2(P<0.01)$. However, there was no interaction between breed and the day of ovariectomy. Relatively small, but significantly positive correlations were detected between testosterone production and mitotic index $(\mathrm{N}=93 ; r=0.26, P<0.01)$ and between testosterone production and granulosa cell number (N $=93 ; r=0.27, P<0.01)$.

Oestrogen-inactive follicles. There was no significant difference between breeds, day of ovariectomy or stage of atresia (Class 1 versus either Class 2 plus 3 or Classes 4-6) for in-vitro oestradiol 
production and follicular diameter. The overall means for these characteristics are shown in Table 5. Of the oestrogen-inactive follicles that were morphologically characterized, $38 \%$ were nonatretic. Using a regression model and fitting breed, atresia, granulosa cell number and in-vitro testosterone production, the only variable to contribute significantly to the variation in in-vitro oestradiol production was granulosa cell number $(P<0 \cdot 05)$. There were also significant correlations between oestradiol production and granulosa cell number $(r=0.36, P<0.05)$ and between in-vitro granulosa cell number and mitotic index $(r=-0.43, P<0.01)$ in healthy oestrogeninactive follicles. Whatever the atresia class, there were positive correlations between in-vitro oestradiol production and both granulosa cell number (Class $2 \& 3, r=0.68, P<0.001$; Class 4, $r=0.42$, $P<0.01$ ) and in-vitro testosterone production (Class $2 \& 3, r=0.44, P<0.05$; Class $4, r=0.43$, $P<0.01)$. In Class 4 follicles there was also a significant positive correlation between in-vitro testosterone production and granulosa cell number $(r=0.54, P<0.001)$.

Table 5. Geometric mean ( \pm s.e.m. no. of follicles in parentheses) follicular characteristics in oestrogen-inactive follicles

\begin{tabular}{lccc}
\hline & $\begin{array}{c}\text { Finnish } \\
\text { Landrace }\end{array}$ & $\begin{array}{c}\text { Finnish Landrace } \times \\
\text { Scottish Blackface }\end{array}$ & $\begin{array}{c}\text { Merino } \times \\
\text { Scottish Blackface }\end{array}$ \\
\hline $\begin{array}{l}\text { In-vitro oestradiol production } \\
(\mathrm{pg} / \mathrm{ml} / \mathrm{h})\end{array}$ & $19.2 \pm 2.7$ & $18.4 \pm 2.0$ & $16 \cdot 1 \pm 1 \cdot 6$ \\
Diameter $(\mathrm{mm})^{* \dagger}$ & $(46)$ & $(71)$ & $(89)$ \\
Granulosa cell no. $\left(\times 10^{-6}\right) \dagger$ & $2 \cdot 2 \pm 0.2$ & $2.3 \pm 0.2$ & $(33)$ \\
& $0.47 \pm 0.06$ & $0.58 \pm 0.06$ & $0.61 \pm 0.07$ \\
\end{tabular}

*Follicle diameters were measured during histological processing and are presented as arithmetic means.

†The results do not include follicles in Stages 5 and 6 of atresia, or follicles damaged at the time of dissection or histological processing.

For in-vitro testosterone production $(\mathrm{pg} / \mathrm{ml} / \mathrm{h})$ there was a significant difference between breed and also between stage of atresia (Table 6). In Class 1 (healthy) follicles there was a significant difference between breed $(P<0.01)$ for in-vitro testosterone production, with the Merino $\times$ Scottish Blackface group having significantly higher concentrations. In Class 2 and 3 follicles, both the Finnish Landrace $\times$ Scottish Blackface and the Merino $\times$ Scottish Blackface groups had significantly higher concentrations compared to the Finnish Landrace ewes $(P<0.05)$. There was no significant difference between breeds for follicles at Stages 4-6 of atresia. Furthermore, for each breed, Class 1 (healthy) follicles produced significantly more testosterone than follicles in more advanced stages of atresia $(P<0.05)$.

Table 6. Geometric mean ( \pm s.e.m. for the no. of observations in parentheses) in-vitro testosterone production $(\mathrm{pg} / \mathrm{ml} / \mathrm{h})$ by oestrogen-inactive follicles

\begin{tabular}{lccc}
\hline $\begin{array}{l}\text { Class of } \\
\text { atresia }\end{array}$ & $\begin{array}{c}\text { Finnish } \\
\text { Landrace }\end{array}$ & $\begin{array}{c}\text { Finnish Landrace } \times \\
\text { Scottish Blackface }\end{array}$ & $\begin{array}{c}\text { Merino } \times \\
\text { Scottish Blackface }\end{array}$ \\
\hline Healthy, Class I & $602 \pm 210^{\mathrm{a}}$ & $420 \pm 103^{\mathrm{a}}$ & $1353 \pm 304^{\mathrm{b}}$ \\
Classes $2+3$ & $76 \pm 46^{\mathrm{a}}$ & $513 \pm 175^{\mathrm{b}}$ & $(20)$ \\
Classes 4-6 & $(5)$ & $(13)$ & $380 \pm 120^{\mathrm{b}}$ \\
& $126 \pm 23$ & $128 \pm 20$ & $(15)$ \\
& $(32)$ & $(41)$ & $145 \pm 20$ \\
\hline
\end{tabular}

Across rows mean values with different superscripts differ $(P<0.05)$. 


\section{Discussion}

The measurement of in-vitro oestradiol production by individual follicles has demonstrated the presence of two distinct populations; oestrogen-active follicles, for which the mean number of follicles per ewe was equivalent to the ovulation rate for the breed, and oestrogen-inactive follicles, which include either developing and growing follicles or follicles undergoing atresia. There was also good agreement between the three techniques used; ink-labelling to follow follicular growth, invitro oestradiol as a measure of follicle maturity and histological examination for assessing atresia. On $>90 \%$ of occasions identification of the ovulatory follicle using in-vitro oestradiol production was confirmed by the ink-labelling and histological results. There is an inverse relationship between oestradiol production and stage of atresia (Moor et al., 1978) and the results presented here support this conclusion. However, as follicles grow they pass through an androgen-dominated phase (Moor et al., 1978; Carson et al., 1981; England et al., 1981a,b), and morphological information is therefore required to classify precisely non-oestrogenic follicles as atretic or healthy.

Several important conclusions have resulted from the integration of the three techniques. Firstly, recruitment of follicles into the population of gonadotrophin-dependent follicles and selection of ovulatory follicles are controlled by different mechanisms. Secondly, there are differences in the morphological and functional differentiation of ovulatory follicles in higher ovulation-rate Finnish Landrace ewes compared to the lower ovulation-rate breeds.

Firstly, follicular growth patterns changed as ovulation approached. For example, between the late luteal phase (Day PG - 1) and the early follicular phase (Day PG +1 ) the number of growing follicles per breed was similar. However, over the next $24 \mathrm{~h}$ (Days PG +1 to $\mathrm{PG}+2$ ) the number of follicles continuing to grow was reduced, being similar to the ovulation rate for the breed. This supports the concept that in these three breeds the selection of ovulatory follicles had occurred by oestrus, the remaining recruited follicles going atretic. The ovulation rate was not positively correlated to the large antral follicle population (see review by Bindon \& Piper, 1986) as the Finnish Landrace ewes had fewer antral follicles of $\geqslant 1 \mathrm{~mm}$ diameter than did the other two breeds. Possible contenders for the mechanisms controlling follicular selection into the ovulatory follicle pool include LH and FSH. However, the exact role of gonadotrophins in the control of recruitment and selection has not been fully clarified (Webb \& Gauld, 1987; McNatty \& Henderson, 1987; Driancourt \& Fry, 1988). There were no differences in FSH concentrations when Finnish Landrace ewes were compared to either lower ovulation-rate Suffolk ewes (Webb \& England, 1982a) or Galway ewes (Adams et al., 1988). In the same experiments, LH concentrations were either the same (Adams et al., 1988) or lower (Webb \& England, 1982a) in Finnish Landrace compared to the Galway and Suffolk breeds. Although LH pulse frequency has not been assessed in Finnish Landrace ewes, the same ovulation rate can be achieved in Finnish Landrace $\times$ Dorset Horn ewes, despite different patterns of LH secretion (McNeilly et al., 1988). Moreover, mature follicles, possessing significant numbers of granulosa cell LH receptors, are present during the luteal phase and the number of these mature follicles is the same as the ovulation rate (England et al., 1981b). Corpora lutea can also be induced by hCG treatment during the luteal phase of the oestrous cycle in Merino ewes (see review by Scaramuzzi \& Hoskinson, 1984) and in Romanov and Ile-de-France ewes (Driancourt et al., 1988); the number of induced CL is typical of the breed. The mechanism(s) controlling ovulation rate is (are) therefore present during both the luteal and follicular phase of the oestrous cycle (Webb \& Gauld, 1985a,b) and this argues against changes in the pattern of gonadotrophin secretion being responsible for the breed differences in ovulation rate.

Secondly, there are differences in the pattern of follicular differentiation in Finnish Landrace ewes compared to the other genotypes. These include an extended period of selection, an increased ability of granulosa cells to secrete oestradiol and a reduced mitotic index. Finnish Landrace ewes select approximately $40 \%$ of the ovulatory follicles during the follicular phase compared with only $6 \%$ in the Merino $\times$ Scottish Blackface ewes (Table 2). However, even in the Finnish Landrace ewes the largest oestrogen-active follicle had been ink-labelled on the day before the start of 
luteolysis. A similar phenomenon of the later selection of ovulatory follicles has been demonstrated in Booroola ewes (Driancourt et al., 1985; see review by Bindon \& Piper, 1986) and may be a characteristic common to other prolific sheep breeds.

The ability of ewes with the Booroola gene to select follicles at a late stage in the follicular phase has been associated with a smaller ovulatory follicle (McNatty et al., 1985; Driancourt et al., 1985). Ovulatory follicles in Finnish Landrace ewes have a size range starting at a smaller diameter compared to Scottish Blackface ewes (Webb \& Gauld, 1985b). This was confirmed in this study, as Finnish Landrace ewes had a higher proportion of follicles in the 4-6 mm range and significantly less in the $>6.0 \mathrm{~mm}$ range compared with the other two breeds (Fig. 3). The Finnish Landrace ewes also had significantly fewer granulosa cells per oestrogen-active follicle, similar to some other prolific breeds, such as the Booroola Merino and Booroola $\times$ Romanov (Baird et al., 1982; Scaramuzzi \& Radford, 1983; McNatty et al., 1985; Driancourt et al., 1985, 1986) although Romanov ewes are different (Driancourt \& Fry, 1988). The number of granulosa cells in oestrogen-active follicles in the Merino $\times$ Scottish Blackface ewes is similar to that reported previously for Merino ewes (Baird et al., 1982).

There was no between-breed difference for in-vitro oestradiol production despite the finding that the number of granulosa cells contributes significantly to the variation in in-vitro oestradiol production and that Finnish Landrace ewes have significantly fewer granulosa cells. This suggests that, on a per cell basis, granulosa cells of Finnish Landrace ewes produce more oestradiol in vitro. This effect cannot be explained by an increase in the availability of androgen precursor as Finnish Landrace ewes had lower testosterone production, even after correction for granulosa cell number. Furthermore testosterone production was significantly higher on Day PG +2 unlike oestradiol production. These results differ from previous reports for the Booroola strain of Merino in which oestradiol production per cell appeared to be unaffected by strain, while there were no differences between strains in follicular fluid testosterone concentrations (McNatty et al., 1986). This suggests that some of the mechanisms controlling the differentiation of ovulatory follicles may differ between Finnish Landrace ewes and ewes possessing the Booroola gene.

The reduced granulosa cell number in Finnish Landrace ewes may be related to the significantly reduced mitotic index. The mitotic indices in this study are similar to those reported by Cahill $\&$ Mauléon (1980). However, they reported no breed difference between Romanov and Ile-de-France ewes, although the group sizes were approximately half of those reported in this study. Expressed on a per ewe basis, Merino $\times$ Scottish Blackface ewes had significantly fewer granulosa cells in oestrogen-active follicles compared to Finnish Landrace ewes with the Finnish Landrace $\times$ Scottish Blackface ewes intermediate.

In conclusion this study has demonstrated that some of the characteristics of follicular differentiation are different in prolific Finnish Landrace ewes compared to lower ovulation rate breeds. This study has also confirmed that different mechanisms control follicular recruitment and follicular selection. While gonadotrophins are required for the growth of follicles, particularly those $>2$ mm diameter (Dufour et al., 1979; McNeilly et al., 1986; Driancourt et al., 1988; Webb \& Gauld, 1985a,b), differences in the pattern of gonadotrophin secretion within the physiological range may not be responsible for differences in ovulation rate. Two recent studies in hypophysectomized ewes support this conclusion (Fry et al., 1988; Driancourt et al., 1988), and suggest that the control of ovulation rate may be due primarily to ovarian rather than pituitary factors. Future work should be aimed at the delineation of these mechanisms and the identification of the possible ovarian factors involved.

We thank G. Baxter, D. McBride, P. Hutchings, M. Ritchie, M. Thomson, C. Manson and the Dryden Staff for technical assistance; A. J. Springbett for the statistical analyses; W. Ritchie for art work; J. E. T. Corrie for reagents for the progesterone assay; J. Cherrie for typing the manuscript; and M. Durand for histological preparation of the follicles. The support of M.A.D. by the EEC is gratefully acknowledged. 


\section{References}

Adams, T.E., Quirke, J.F., Hanrahan, J.P., Adams, B.M. \& Watson, J.G. (1988) Gonadotrophin secretion during the periovulatory period in Galway and Finnish Landrace ewes and Finnish Landrace ewes selected for high ovulation rate. J. Reprod. Fert. 83, 575-584.

Baird, D.T., Ralph, M.M., Seamark, R.F., Amato, F. \& Bindon, B.M. (1982) Pre-ovulatory follicular activity and oestrogen secretion of high (Booroola) and low fertility Merino ewes. Proc. Aust. Soc. Reprod. Biol. 14,83 , abstr.

Bindon, B.M. \& Piper, L.R. (1986) The reproductive biology of prolific sheep breeds. Oxford Rev. Reprod. Biol. 8, 414451.

Cahill, L.P. \& Mauléon, P. (1980) Influences of season, cycle and breed on follicular growth rates in sheep. $J$. Reprod. Fert. 58, 321-328.

Carson, R.S., Findlay, J.K., Burger, H.G. \& Trounson, A.O. (1979) Gonadotropin receptors of the ovine ovarian follicle during follicular growth and atresia. Biol. Reprod. 21, 75-87.

Carson, R.S., Findlay, J.K., Clarke, I.J. \& Burger, H.G. (1981) Estradiol, testosterone and androstenedione in ovine follicular fluid during growth and atresia of ovarian follicles. Biol. Reprod. 24, 105-113.

Clarke, I.J. \& Doughton, B.W. (1983) Effect of various anaesthetics on resting plasma concentrations of luteinizing hormone, follicle stimulating hormone and prolactin in ovariectomized ewes. $J$. Endocr. 98, 79-89.

Corrie, J.E.T., Hunter, W.M. \& Macpherson, J.S. (1981) A strategy for radioimmunoassay of plasma progesterone with the use of a homologous site ${ }^{125} \mathrm{I}$ labelled radioligand. Clin. chem. 27, 594-599.

Driancourt, M.A. \& Cahill, L.P. (1984) Preovulatory events in sheep. J. Reprod. Fert. 71, 205-211.

Driancourt, M.A. \& Fry, R.C. (1988) Differentiation of ovulatory follicles in sheep. J. Anim. Sci. 66 (Suppl. 12), 9-20.

Driancourt, M.A., Cahill, L.P. \& Bindon, B.M. (1985) Ovarian follicular populations and preovulatory enlargement in Booroola and control Merino ewes. $J$. Reprod. Fert. 73, 93-107.

Driancourt, M.A., Gauld, I.K., Terqui, M. \& Webb, R. (1986) Variations in patterns of follicle development in prolific breeds of sheep. J. Reprod. Fert. 78, 565-575.

Driancourt, M.A., Philipon, P., Locatelli, A., Jacques, E. \& Webb, R. (1988) Are differences in FSH concentrations involved in the control of ovulation rate in Romanov and Ile-de-France ewes? J. Reprod. Fert. 83, 509-516.

Dufour, J.J., Cahill, L.P. \& Mauleon, P. (1979) Short and long term effects of hypophysectomy and unilateral ovariectomy of ovarian follicular populations in sheep. J. Reprod. Fert. 57, 301-309.

England, B.G., Dahmer, M.K. \& Webb, R. (1981a) Relationships between follicular size and antral fluid steroid concentrations at three stages of the estrous cycle in the ewe. Biol. Reprod. 24, 1068-1075.

England, B.G., Webb, R. \& Dahmer, M.K. (1981b) Follicular steroidogenesis and gonadotrophin binding to ovine follicles during the estrous cycle. Endocrinology $109,881-887$.
Fry, R.C., Clarke, I.J., Cummins, J.T., Bindon, B.M., Piper, L.R. \& Cahill, L.P. (1988) Induction of ovulations in chronically hypophysectomized Booroola ewes. J. Reprod. Fert. 82, 711-715.

Gougeon, A. (1981) Cinetique de follicles ovariens pendant le cycle menstruel chez la femme. D.Sc. thesis, University of Paris VI.

McNatty, K.P. \& Henderson, K.M. (1987) Gonadotrophins, fecundity genes and ovarian follicular functions. J. Steroid Biochem. 27, 365-373.

MeNatty, K.P., Henderson, K.M., Lun, S., Heath, D.A., Ball, K., Hudson, N.L., Fannin, J., Gibb, M., Kieboom, L.E. \& Smith, P. (1985) Ovarian activity in Booroola $\times$ Romney ewes which have a major gene influencing their ovulation rate. J. Reprod. Fert. $\mathbf{7 3}$, 109-120.

McNatty, K.P., Lun, S., Heath, D.A., Ball, K., Smith, P., Hudson, N.L., McDiarmid, J., Gibb, M. \& Henderson, K.M. (1986) Differences in ovarian activity between Booroola $\times$ Merino ewes which were homozygous, heterozygous and non-carriers of a major gene influencing their ovulation rates. J. Reprod. Fert. 77, 193-205.

McNeilly, A.S., Jonassen, J.A. \& Fraser, H.M. (1986) Suppression of follicular development after chronic LHRH immunoneutralization in the ewe. J. Reprod. Fert. 76, 481-490.

McNeilly, J.R., Fordyce, M., Land, R.B., Martin, G.B., Springbett, A.J. \& Webb, R. (1988) Changes in the feedback control of gonadotrophin secretion in ewes from lines selected for testis size in the ram lamb. $J$. Reprod. Fert. 84, 213-221.

Moor, R.M., Hay, M.F., Dott, H.M. \& Cran, D.G. (1978) Microscopic identification and steroidogenic function of atretic follicles in sheep. J. Endocr. 77, 309318.

Pedersen, T. (1970) Follicle kinetics in the ovary of the cyclic mouse. Acta endocr., Copenh. 64, 304-323.

Scaramuzzi, R.J. \& Hoskinson, R.M. (1984) Active immunization against steroid hormones for increasing fecundity. In Immunological Aspects of Reproduction of Mammals, pp. 445-474. Ed. D. B. Crighton, Butterworths, London.

Scaramuzzi, R.J. \& Radford, N.M. (1983) Factors regulating ovulation rate in the ewe. J. Reprod. Fert. 69, 353-367.

Scheffe, H. (1959) The Analysis for Variance. Wiley, New York.

Turnbull, K.E., Braden, A.W.N. \& Mattner, P.E. (1977) The pattern of follicular growth and atresia in the ovine ovary. Aust. J. biol. Sci. 30, 229-241.

Webb, R. (1987) Increasing ovulation and lambing rate in sheep by treatment with a steroid enzyme inhibitor. J. Reprod. Fert. 79, 231-240.

Webb, R. \& England, B.G. (1982a) Identification of the ovulatory follicle in the ewe: associated changes in follicular size, thecal and granulosa cell LH receptors, antral fluid steroids and circulating hormones during the preovulatory period. Endocrinology 110, 873-881.

Webb, R. \& England, B.G. (1982b) Relationship between LH receptor concentrations in thecal and granulosa cells and in-vivo and in-vitro steroid secretion by 
ovine follicles during the preovulatory period. $J$. Reprod. Fert. 66, 169-180.

Webb, R. \& Gauld, I.K. (1985a) Genetics and physiology of follicle recruitment and maturation during seasonal anoestrus. In Endocrine Causes of Seasonal and Lactational Anoestrus in Farm Animals, pp. 19-28. Eds F. Ellendorf \& F. Elsaesser. Martinus Nijhoff, Dordrecht.

Webb, R. \& Gauld, I.K. (1985b) Folliculogenesis in sheep: control of ovulation rate. In Genetics of Reproduction in the Sheep, pp. 261-274. Eds R. B. Land \& D. W. Robinson. Butterworths, London.
Webb, R. \& Gauld, I.K. (1987) Endocrine control of follicular growth in the ewe. In Follicular Growth and Ovulation Rate in Farm Animals, pp. 107-118. Eds J. F. Roche \& D. O'Callaghan. Martinus Nijhoff, Dordrecht.

Webb, R., Baxter, G., McBride, D., Nordblom, G.D. \& Shaw, M.P.K. (1985) The measurement of testosterone and oestradiol-17 $\beta$ using iodinated tracers and incorporating an affinity chromatography extraction procedure. J. Steroid Biochem. 23, 1043-1051.

Received 12 January 1989 